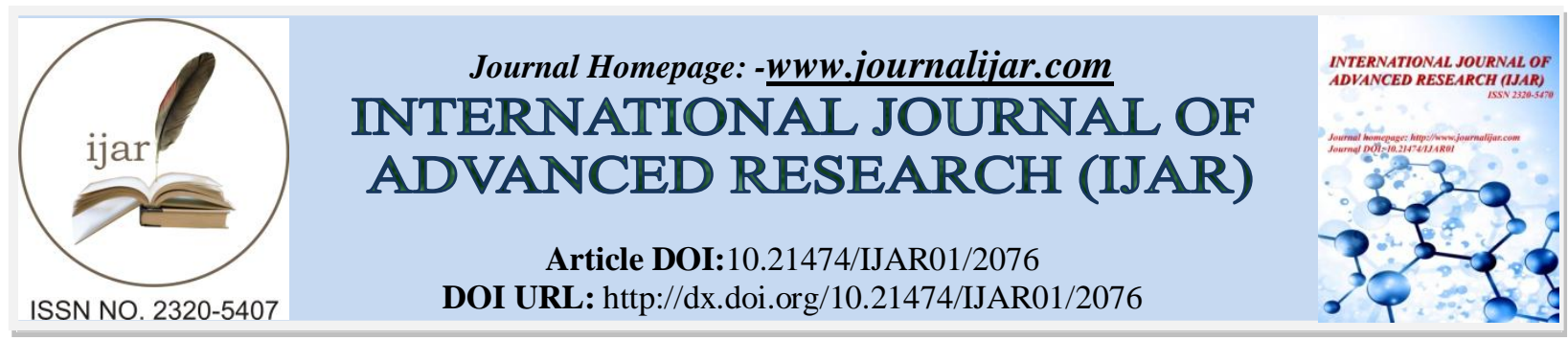

RESEARCH ARTICLE

\title{
DOUBLE LAYERED FLAP FOR CLOSURE OF RECURRENT OROANTRALFISTULAUSING BUCCAL FAT PAD AND PALATAL PEDICLED FLAP - A CASE REPORT.
}

\section{Dr. D. Yesuratnam, Dr. D. Naga Sujata, Dr. S. Balasubramanyam and Dr. P. Anitha}

1. Assistant Professor, Dept. of Oral \& Maxillofacial Surgery, Govt. Dental College\& Hospital, RIMS, Kadapa.

2. Assistant Professor, Dept. of Oral \& Maxillofacial Surgery, Govt. Dental College\& Hospital, RIMS, Kadapa.

3. Professor \& H.O.D, Dept. of Oral \& Maxillofacial Surgery, Govt. Dental College\& Hospital, RIMS, Kadapa.

4. Post Graduate student, Dept. of Oral \& Maxillofacial Surgery, Govt. Dental College\& Hospital, RIMS, Kadapa

\section{Manuscript Info}

Manuscript History

Received: 24 September 2016

Final Accepted: 25 October 2016

Published: November 2016

Key words:-

Oroantral fistula, buccal fat pad, palatal pedicled flap.

\section{Abstract}

Oroantral fistula is a pathological condition which is frequently encountered by dentists following extraction of maxillary premolars and molars,may also develop due to infection, iatrogenic trauma and following removal of maxillary cysts and tumors. Closure of oroantral fistula is still one of the most challenging problems in the field of oral surgery. Various techniques have been proposed in literature only few have gained wide acceptance. Wound dehiscence and persistent fistula is common complication following isolated local flaps, the article thereby stresses the importance of double flap closure in recurrent oroantral fistula using buccal fat pad and palatal pedicled flap. The advantage of using two flaps over one flap is that it provides epithelial covering to both superior and inferior surfaces, presents generous thickness that resists laceration which will result in reduced incidence of postoperative wound dehiscence. Moreover excellent blood supply without loss of vestibular depth makes this flap a valuable option in treatment of posterior maxillary defects that couldnot be repaired by conventional procedures.

Copy Right, IJAR, 2016,. All rights reserved.

\section{Introduction:-}

Oroantral communication is an open connection between oral cavity and maxillary sinus. Oroantral communication happens particularly when a maxillary molar with widely divergent roots that is adjacent to the edentulous spaces requires extraction. In this instance the sinus is likely to have pneumatized into the alveolar process surrounding the tooth which weakens the alveolus. It may also occur when a chronic infection has destroyed the bone between the root and the sinus, injudicious use of instruments forcing the root or tooth into the sinus during attempted extraction and removal of large cystic lesions that encroach on the sinus cavity. Oroantral communications may close spontaneously when the defect size is smaller than $2 \mathrm{~mm}$, blood clot fills the extracted site usually seals such small perforations unless the sinus is infected. However defects $>5 \mathrm{~mm}$ are less likely to close spontaneously and will result in long standing oroantral fistulas $(\mathrm{OAF})^{1}$.

$\mathrm{OAF}$ is an epithelized communication that develops between oral and antral cavities ${ }^{2}$. This leads to regurgitation of oral fluids into the sinus and nasal cavity, foul smelling discharge from the fistula and sinusitis requiring surgical

Corresponding Author:-Dr. D. Nagasujata,

Address:-Assistant Professor, Dept. of Oral \& Maxillofacial Surgery, Govt. Dental College\& Hospital, 
intervention. Variety of surgical procedures have been described in literature, ranging from the use of local and distant flaps to bone grafts and various implant materials for closure of OAF. The choice from among these procedures is influenced by size and location of the defect, the amount and condition of the tissues available for repair $^{3}$, presence of infection ${ }^{4}$, whether primary or recurrent and future prosthetic restorative options. Regardless of the surgical technique, successful closure of OAF must be preceded by complete elimination of sinus pathology, fistulous tract, infection \& degenerated polypoid mucosa and diseased bone ${ }^{3}$.

More popular and widely employed flaps are buccal vestibular flap, palatal flap and buccal fat pad ${ }^{5-8}$ with their own advantages \& limitations. However the most common complication encountered is wound dehiscence following use of these isolated flaps. This paper describes double flap closure technique in repair of a large diameter OAF using BFP and palatal pedicled flap.

\section{Case Report:-}

A 55 years old female patient reported with foul smelling and nasal regurgitation of oral fluids since 6months following extraction of right upper first molar, primary closure was done but met with failure. Clinical examination revealed a fistula in relation to edentulous space of missing tooth fig1.Radiograph confirmed the clinical findings and case was diagnosed as OAF.fig2. Patient's medical history was unremarkable. Patient was put on prophylactic antibiotic coverage with amoxicillin 500mg combined with metronidazole $400 \mathrm{mg}$ 8hrly along with nasal decongestants 1week prior to procedure. Under local anesthesia a trapezoidal buccal mucoperiosteal flap was raised, fistulous tract with inflammatory tissue was excised, thorough curettage was done followed by copious irrigation of sinus cavity with diluted povidone iodine solution to remove any remnants of infected tissue. Bony defect size was approximately $2.0 \mathrm{x} 1.5 \mathrm{cms}$. BFP was exposed through buccal periosteal incision posterior to zygomatic buttress fig 3 with a curved hemostat, gently teased and advanced over the bony defect, preserving thin facial envelope.A palatal pedicled flap was raised through an incision carried out on palatal mucosa incision line was designed taking dimensions of bony defect into consideration. Incision was extended posteriorly upto the soft palate taking care not to severe the greater palatine artery fig4.BFP was secured to the defect margins with simple interrupted sutures using 4-0 vicryl without tension and palatal flap was passively positioned over the defect covering BFP. Finallythe medial edge of buccal mucoperiosteal flap was sutured to the edges of rotated palatal flap so that no part of BFP was exposed into the oral cavity fig5. The residual raw surface on palate was left to heal by secondary intention with formation of granulation tissue. This makes double layered closure of OAF with inner layer of BFP towards the bony defectand outer layer of palatal pedicled flap.

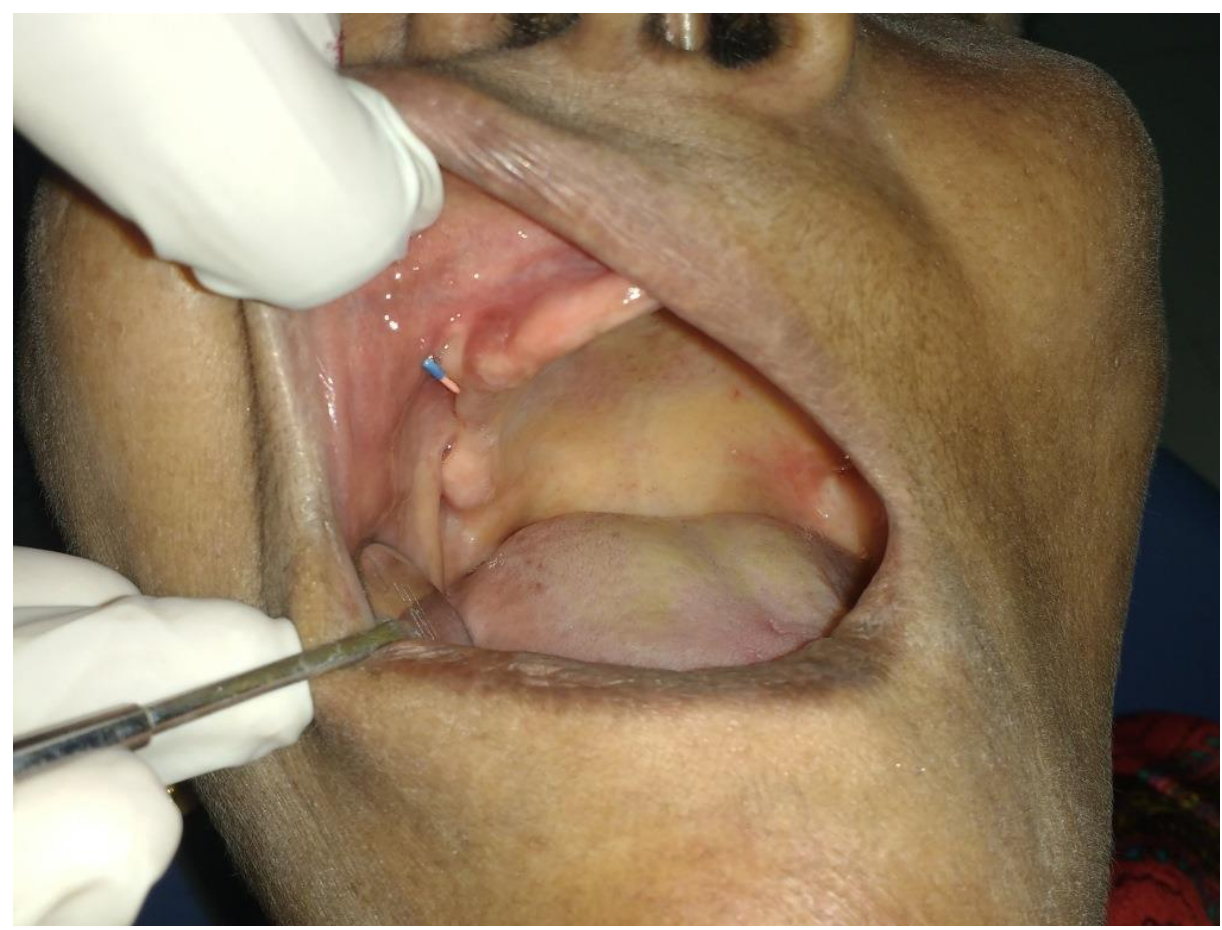

Fig 1:- 


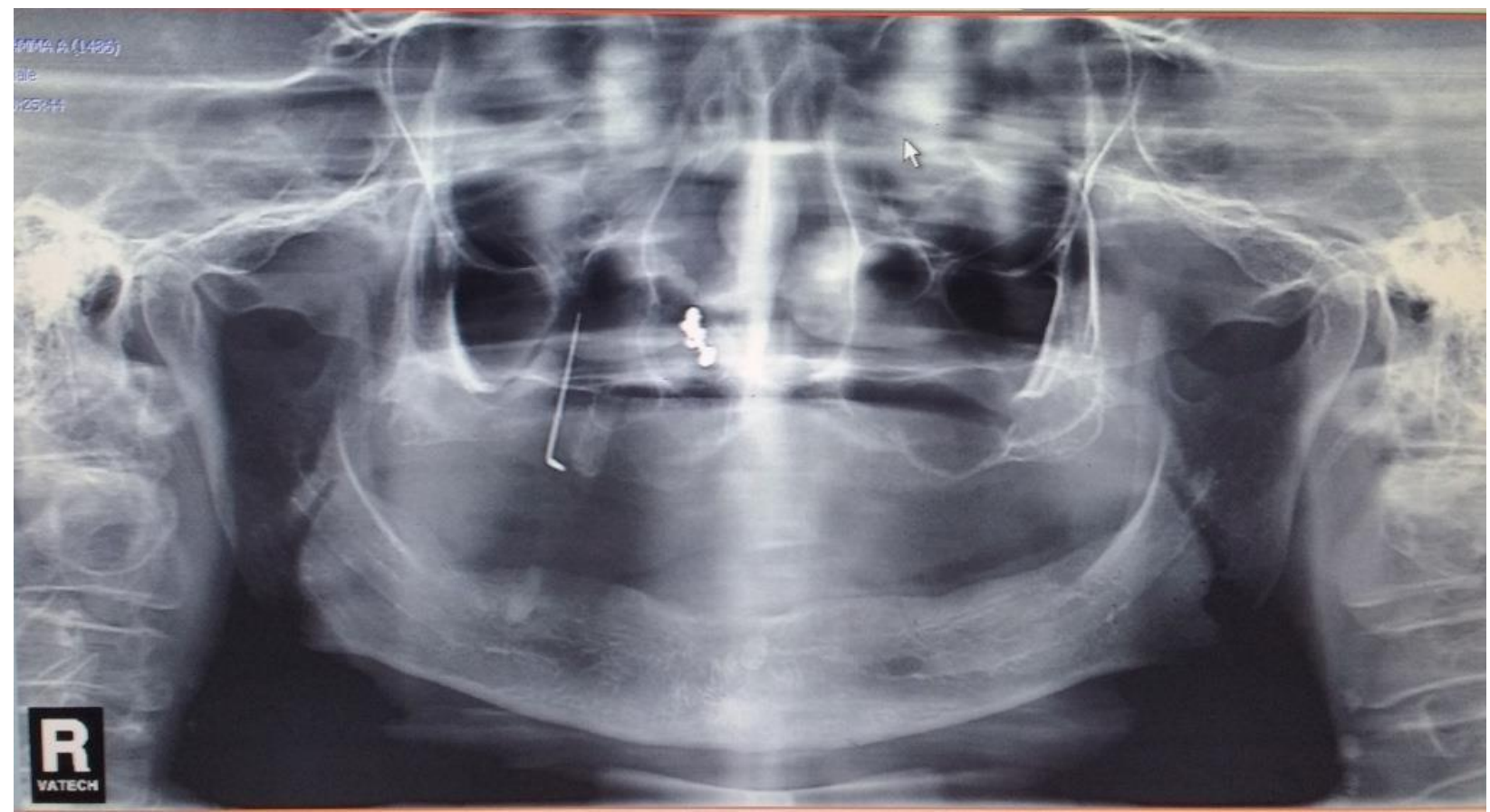

Fig 2:-

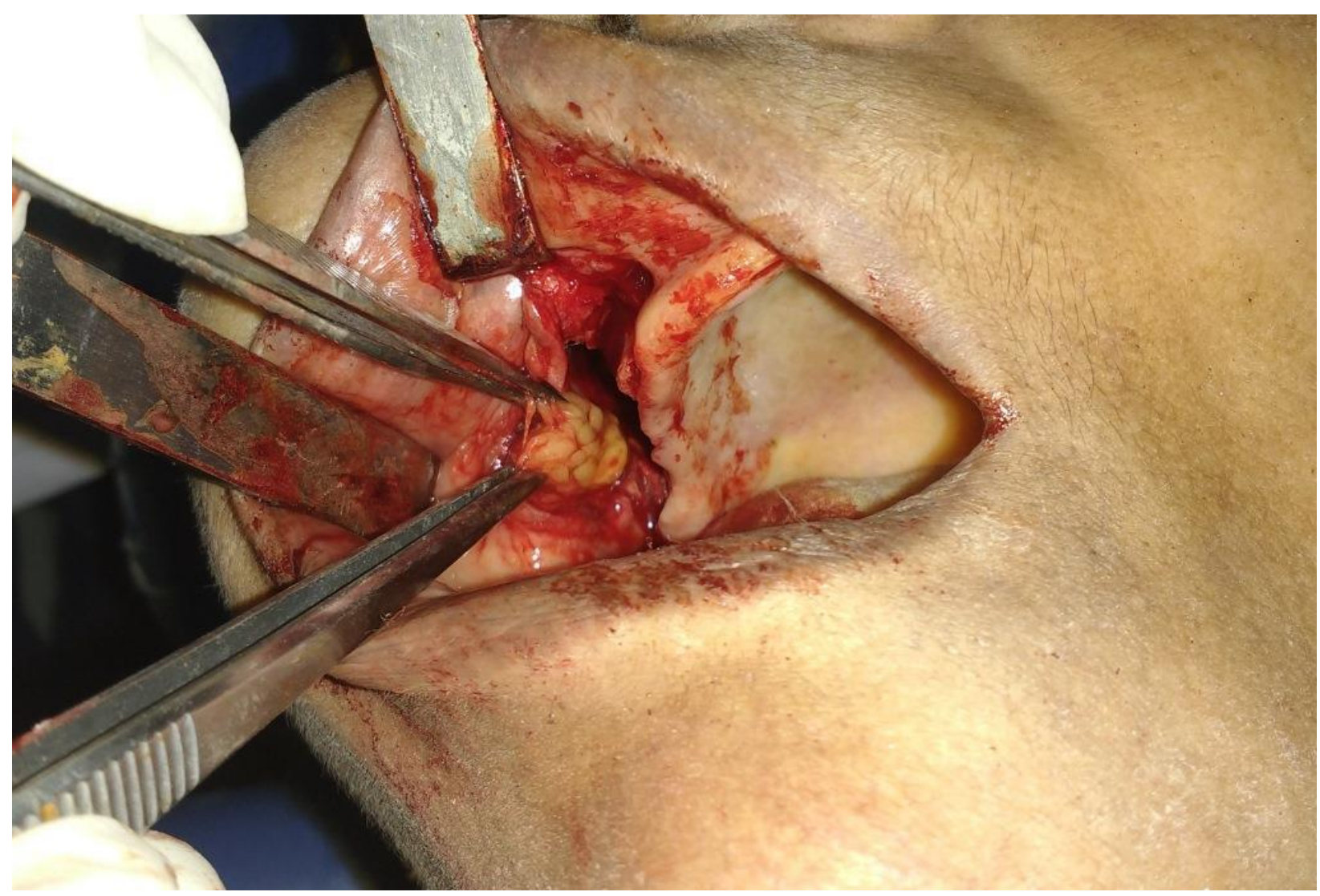

Fig 3:- 


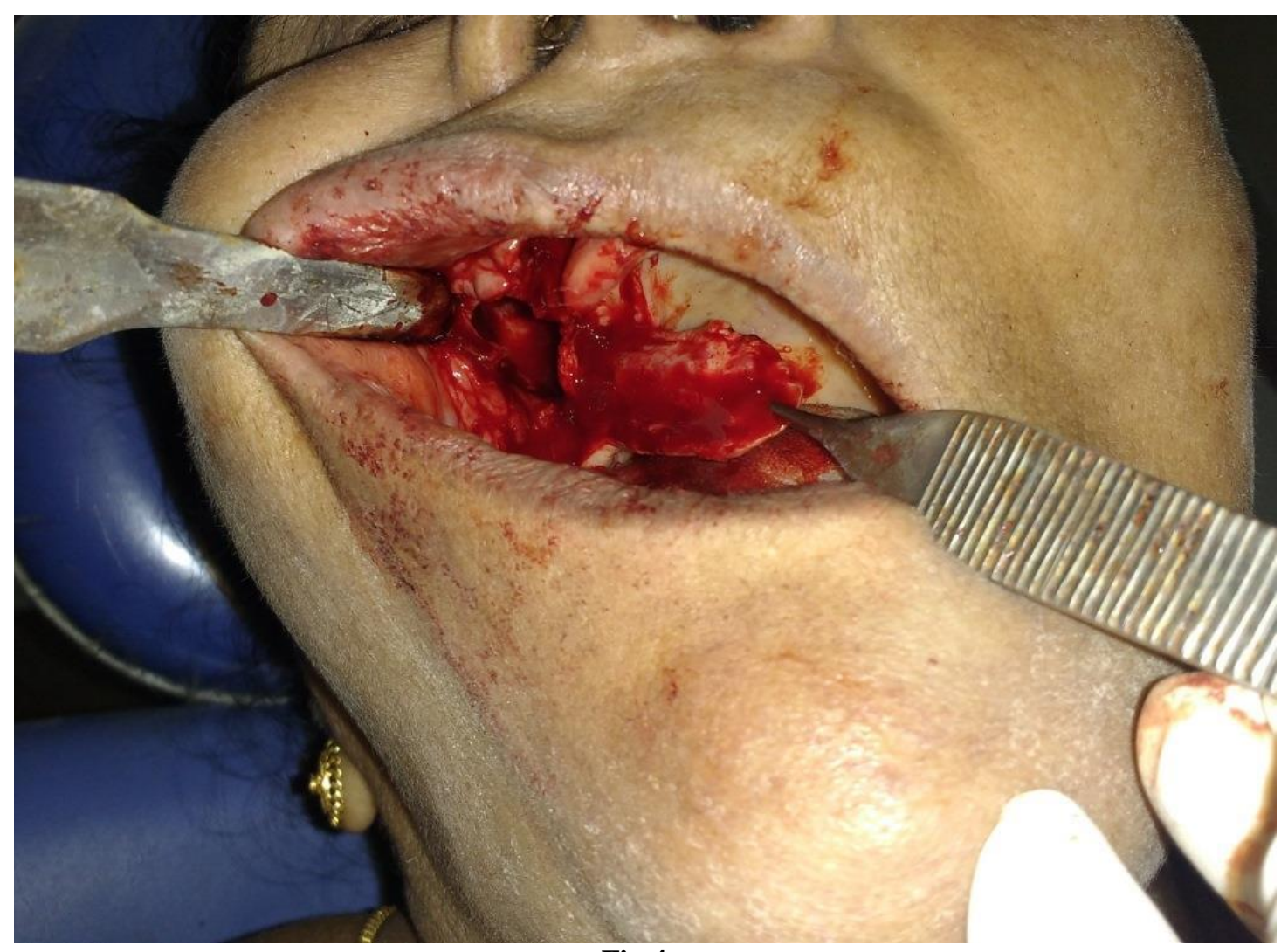

Fig 4:-

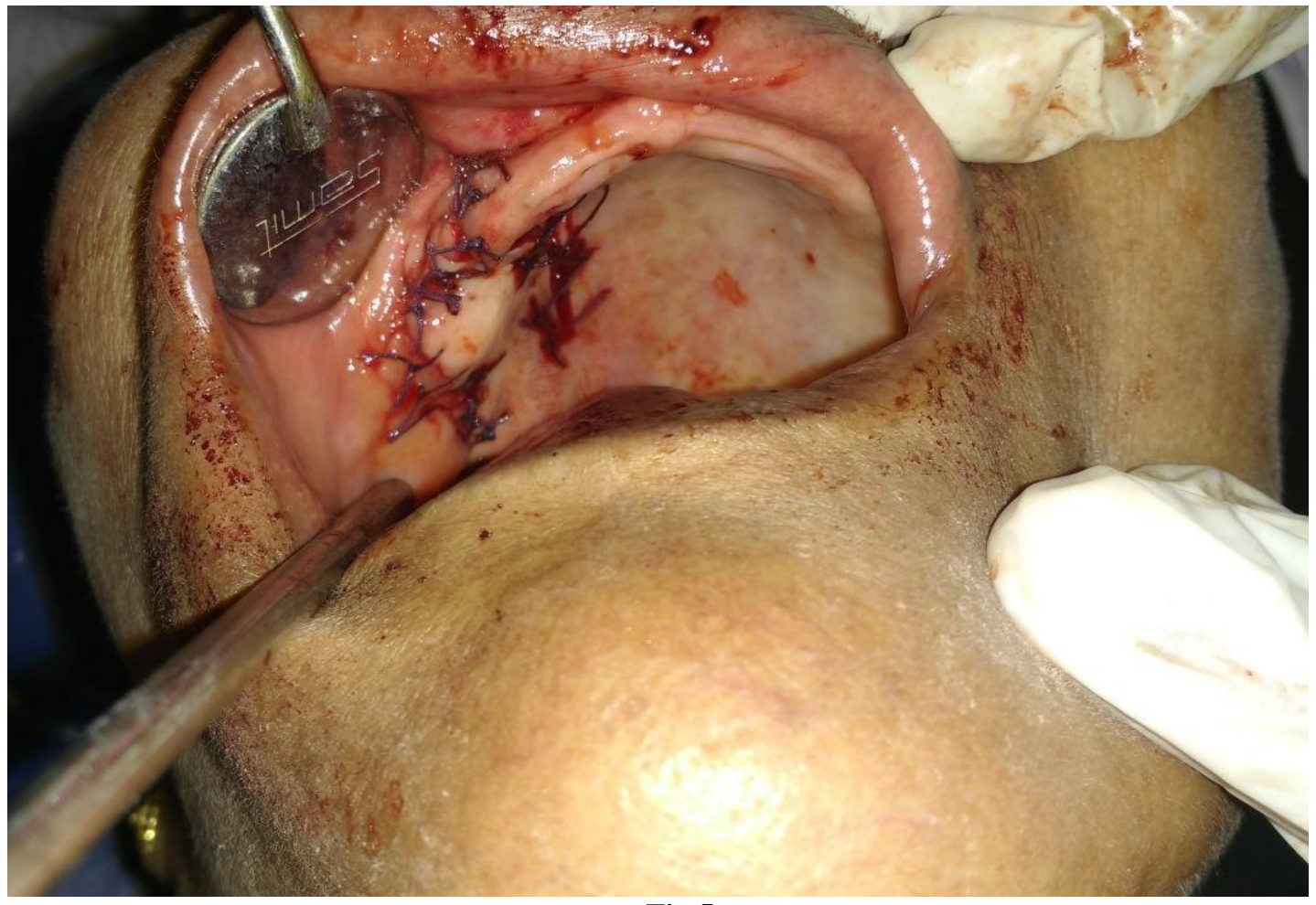

Fig 5 :- 


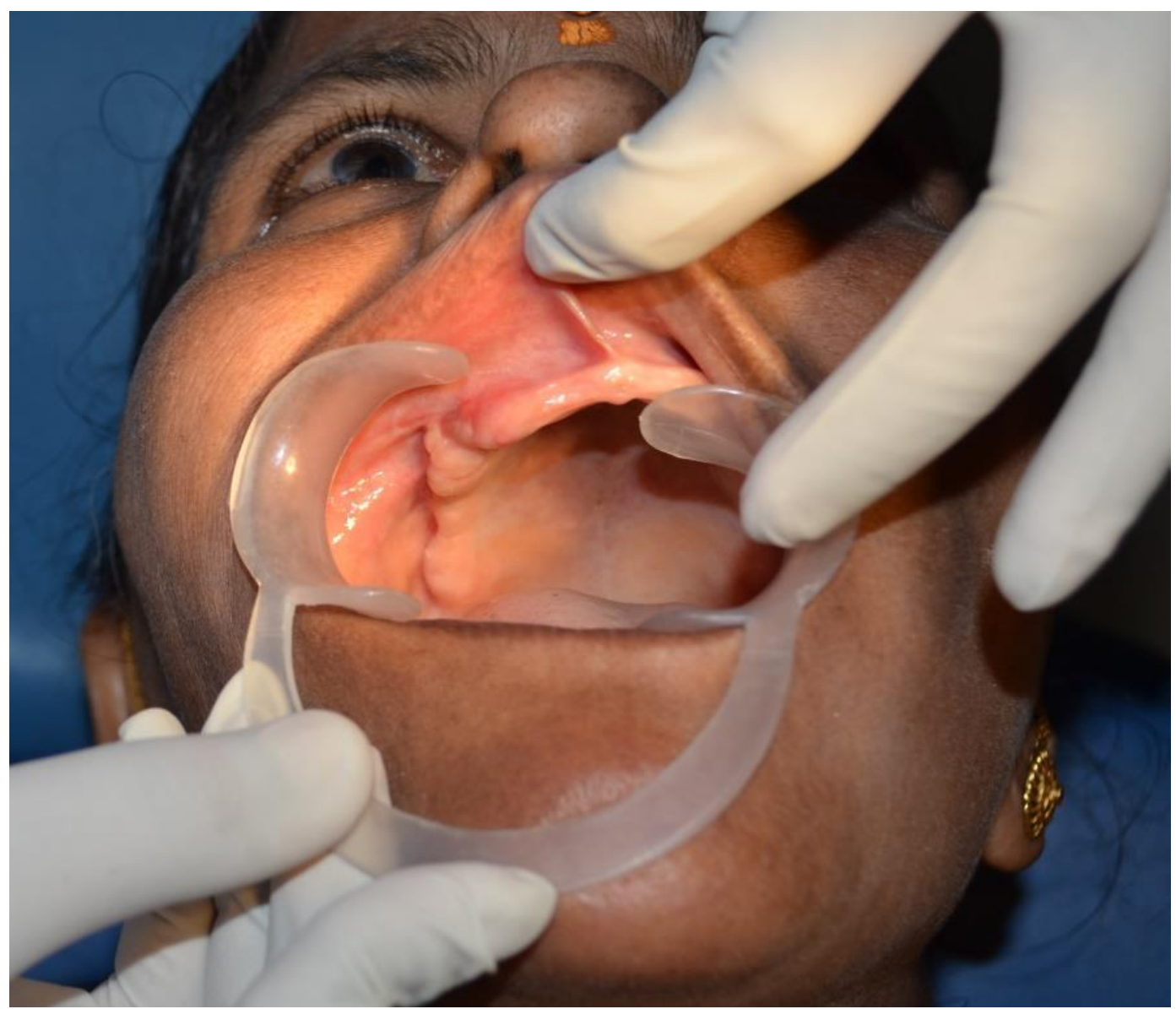

Fig 6:-

Patient was instructed not to blow the nose for 2 weeks. NSAIDS along with preoperative antibiotics were continued for next one week. Patient was reviewed on alternate days for first followed by every week during first postoperative month. Clinical evaluation after 2 weeks revealed granulation tissue at the donor site and acceptable stability at the junction of palatal pedicled flap and receptor site. Complete epithelization of donor site was present at the end of $4^{\text {th }}$ week with no postoperative complications fig6.

\section{Discussion:-}

Numerous surgical techniques have been described in literature mostly based on mobilizing the tissue and advancing the resultant flap into the defect ${ }^{9,10}$. The most common surgical treatment of OAF is buccal advancement flap procedure designed by Rehrmann ${ }^{11}$. Its broad base assures adequate blood supply, disadvantage include risk of reduction of buccal sulcus depth. A prospective followup study by vonwowern ${ }^{12}$ demonstrated that reduction of sulcus depth after Rehrmann method is permanent in half of the cases. In the present case the patient is completely edentulous and maintenance of adequate vestibular depth was of prime importance, we did not prefer buccal advancement flap technique.

The palate derived flaps features several advantages which makes it the first choice for several authors in the literature ${ }^{13,14,15}$. First author to report the use of palatal flap was Ashley 1939 since then several variations of the original technique have been described such as anteriorly based palatal flap ${ }^{16}$, the tunnel palatal flap ${ }^{1}$,the dividedflap ${ }^{13}$ and the random palatal flap ${ }^{14}$. Random palatal flap is based on the anastomoses spread throughout the palate, rest rely on greater palatine artery for nutrition. Advantages of palatal flap are its insured vascularity and thickness of the tissue which closely resembles the attached gingiva on the crest of the ridge and resists laceration.

Recently because of various advantages, BFP is increasingly being employed in repair of OAF and other defects. Initially described by Egyedi ${ }^{17}$, this technique reportedly allows buccal sulcus preservation and uses tissue that is 
highly vascularized. Added advantage is it is prone to reepithelization and can be harvested next to receptor site $^{18,19,20}$. However volume of BFP varies among persons may lead to inadequacy and if excessively stretched there is high risk of postoperative wound dehiscence ${ }^{21}$.

Attempts to close larger defects with single local flaps sometimes have led to failure,various double layered closures using local tissues have been used. These include combination of inversion and rotational advancement flaps ${ }^{22,23,24}$ double overlapping hinged flaps ${ }^{25}$, double island flaps ${ }^{26}$ and superimposition of reverse palatal and buccal flaps $^{27}$. In the present case we used BFP over the defect covered which was breasted by palatal pedicled flap. The advantage of two flaps is that it provides epithelial covering to both the surfaces adds to the thickness of the graft which will result in reduction of incidence of contracture thereby decreasing the chances of wound dehiscence.

\section{Conclusion:-}

The method of closure should be chosen based on individual needs and surgeon should select the simplest method that suits the clinical situation. Regardless of the technique, the criteria for successful closure of OAF are elimination of infection, tension free closure with a well vascularized flap with suture line on solid bone. Hereby we conclude thatmultilayered wide release flaps are essential to ensure a good blood supply and better viability which will result in good healing and this double layered flap is a reliable solution for the closure of medium to large sized defects.

\section{References:-}

1. Yalcin S, Oncu B, Emes Y, Atalay B, Aktas I. Surgical treatment of oroantral fistulas: a clinical study of 23 cases. J Oral Maxillofac Surg. 2011;69(2):333-9.

2. Lazow Stewart K. Surgical management of the oroantral fistula flapprocedures. Oper Tech Otolaryngol Head Neck Surg.1999;10(2):148-152

3. Awang MN: Closure of oroantral fistula. Int J Oral MaxillofacSurg 17:110, 1988

4. Abuabara A, Cortez ALV, Passeri LA, et al: Evaluation of different treatments for oroantral/oronasal communications. IntJ Oral MaxillofacSurg 35:155, 2006

5. Hanzawa Y, Itoh K, Mabashi T, Sato K (1995) Closure of Oro-antral Communication Using A Ped-icle Buccal Fat Pad Graft. J Oral MaxillofacSurg (7): 771-775.

6. Rapidis AP, Alexandridis CA, Eleflheriadis E, Angelopaulos AP (2000) The Use of BFP For Recon-struction Of Oral Defects: Review Of Literature And Report Of 15 Cases. J Oral MaxillofacSurg 58(2): 158-163.

7. Samman N, Cheung L.K, Tideman H. The buc-cal fat pad in oral reconstruction. Int J Oral Maxillo-fac Surg. 1993;22:2-6.

8. Fujimura N, Nagura H, Enomoto S. Grafting of the buccal fat pad into palatal defects. J Cranio-maxillofac Surg. 1990;18:219-22.

9. Axhausen G: Zur Methodic Des VerschlussesVonDefektenImAlveolarforsatzOberkiefer. Deutsche Monatschrift Fur Zahnheilkunde1930;48:193-196. Cited InAwang MN (1988) Closure Of Oro-antral Fis-tula. Int J Oral MaxillofacSurg 17(2): 110-115.

10. Licameli GR, Dolan R (1998) BuccinatorMusculomucosal Flap. Arch Otolaryngol Head Neck Surg 124(1): 6972.

11. Rehrmann VA: Einemethodezurschliessung von kieferhohlenperforationen. DtschZahnartlWochenzeitschr 39:1136, 1936.

12. vonWowern N: Closure of oroantral fistula with buccal flap: Rehrmann versus Moczar. Int J Oral Surg 11:156, 1982

13. Yamazaki Y, Yamaoka M, Hirayama M, Shimada H. The submucosal island flap in the closure of oro-antral fistula. Br J Oral Maxillofac Surg. 1985;23(4):259-63. doi:10.1016/0266-4356(85)90041-5

14. Lee JJ, Kok SH, Chang HH, Yang PJ, Hahn LJ, Kuo YS. Repair of oroantral communications in the third molar region by random palatal flap. Int J Oral Maxillofac Surg. 2002;31(6):677-80. doi:10.1054/ijom.2001.0209

15. Anavi Y, Gal G, Silfen R, Calderon S. Palatal rotationadvancementflap for delayed repair of oroantral fistula: a retrospective evaluation of 63 cases. Oral Surg Oral Med Oral Pathol Oral RadiolEndod. 2003;96(5):527-34. doi:10.1016/S1079-2104(03)00470-

16. Salins PC, Kishore SK: Anteriorly based palatal flap for closure of large oroantral fistula. Oral Surg Oral Med Oral Pathol Oral RadiolEndod 82:253, 1996

17. Egyedi P: Utilization of the buccal fat pad for closure of oroantral and/or oro-nasal communications. $\mathbf{J}$ MaxillofacSurg 5:241, 1977 
18. Poeschl PW, Baumann A, Russmueller G, Poeschl E, Klug C, Ewers R. Closure of oroantral communications with Bichat's buccal fat pad. J Oral Maxillofac Surg. 2009;67(7):1460-6. doi:10.1016/j.joms.2009.03.049

19. Hanazawa Y, Itoh K, Mabashi T, Sato K. Closure of oroantral communications using a pedicled buccal fat pad graft. J Oral Maxillofac Surg. 1995;53(7):771-6. doi:10.1016/0278- 2391(95)90329-1

20. Jain MK, Ramesh C, Sankar K, LokeshBabu KT. Pedicled buccal fat pad in the management of oroantral fistula: a clinical study of 15 cases. Int J Oral Maxillofac Surg. 2012;41(8):1025-9. doi:10.1016/j.ijom.2012.02.014

21. Candamourty R, Jain MK, Sankar K, Babu MR. Double-layered closure of oroantral fistula using buccal fat pad and buccal advancement flap. J Nat SciBiol Med. 2012;3(2):203-5. Do 10.4103/0976-9668.101930

22. Fickling BW. Oral surgery involving maxillary sinus. Ann R Coll Surg. 1957;20:13-25.

23. Gordon NC, Brown SL. Closure of oronasoantral defects. Report of case. J Oral Surg. 1980;38.

24. Quayle AA. Double flap technique for closure of oronasal and oroantral fistula. Br J Oral Surg. 1981;19:132137.

25. Rintala A. A double overlapping hinged flap to close palatal fistula. Stand J PlastReeonstr Surg. 1971;5:91-95.

26. Herbert DC. Closure of a palatal fistula using mucoperiosteal island flap. Br J Plast Surg. 1974;27:332-336.

27. Ziemba RB. Combined buccal and reverse palatal flap for closure of oroantral fistula. J Oral Surg. 1972;30:722-730. 